\title{
Functionality of Referring in International Commercial Arbitration
}

\author{
Abdorreza Shojaei
}

Faculty of Law, Department of Private Law, Shahid Beheshti University, Tehran, Iran

\section{Doi:10.5901/mjss.2016.v7n3p56}

\begin{abstract}
The emergence of dispute and cases in international trade agreements has leaded both sides to a point to pre-determine cases for fulfillment of failures in the case of problems. In fact, it is a win-win situation when parties resolve the case in a right, secure and specialized way; then, they can return to their former normal trade relations. Economic and commercial areas require that commercial disputes be resolved as soon as possible and in ways appropriate to the needs and economic benefits. In the meantime, "arbitration" is the best and safest measure to achieve this goal. However, the need for arbitration to resolve disputes should be fulfilled with the expansion of trade in the international arena. Hence, a uniform law, called UNCITRAL Arbitration Act, was developed to judge in international commercial arbitrations. Iran is one of the countries that have accepted the Act. By studying the international commercial arbitration rule, this article tries to explain the way of referring to arbitration.
\end{abstract}

Keywords: arbitration, referring, law, international trade.

\section{Introduction}

Nowadays international commercial arbitration is a common and useful approach in resolving international trade disputes among the people that their business is associated with two or more countries.

This method of dispute resolution is an alternative to domestic courts; for the sake of impartiality and efficacy, they have major and significant features that court proceedings in most countries do not possess. The growth of international financial transactions attracted the attention of international trade authorities on the fact that what legal system is appropriate for such interactions; they found the best system to formulate commercial relations and reduce or remove special problems of international transactions for preventing the emergence of mutual disputes and the problems of conflict of laws and unpredictable turnouts. At first, the result of theoretical and practical transactions and solutions brought about commercial conventions among merchants. Second, as governments realized their goals may be in a position of conflict to the business goals of their citizens attempted to regulate, foreign exchange, export and import taxes. Third, public international organizations and international private organizations have been established to prod governments to adopt these laws to the domestic rules by uniform rules that emanate from the conventions joint business in the context of international trade (Ilkhani, 2007: 39).

\section{Arbitrator and Arbitration}

In Persian, Dehkhoda dictionary defines the word arbitrator as the implementation of a verdict for people in the Day of Judgment by God" (Dehkhoda, 1993).

In addition, arbitration is a common way in commercial dispute resolution. In the years after World War II, arbitration was introduced as the most popular international commercial dispute settlement procedure (Strong, 2914: 12). In fact, there are two ways to end the conflicts: judicial settlement and arbitration settlement. Judicial settlement is defined as a legal, unbiased, permanent official decision (Reif, 1990: 580). Moreover, many definitions have been proposed for arbitration; every person has defined it based on his own legal viewpoint. Professor René David presents the most comprehensive definition in his book titled "Arbitration in International Trade". He argues that arbitration is a method in which two or more beneficiary parties appoint one or more persons (arbitrator or arbitrators) whose power in solution rises from a private contract to solve the problems. They should make decisions based on the contract without any need to be authorized by a government (Eskini, 2006: 48).

According to first paragraph of Law on International Commercial Arbitration (1997), arbitration is settling disputes between litigants out of court by a consensual or appointed natural or legal person or persons. Arbitration is also defined as referring dispute to an impartial person (third party) that is chosen by the parties; the parties agree in advance to follow 
the verdict issued by the arbitrator after meeting and hearing the parties statements (Bordbar, 2005: 12). The term has also been defined as referring and submission of the dispute to decision and idea of a person, not competent courts (ibid: 22).

Oxford Dictionary of Law defines it as, "A means of settling disputes without recourse to law. The arbitrator will hear the case of the parties and make either a binding or an indicative judgment (A. Martin, 2005: 13).

With the above definitions, it appears that no definition does convey the exact meaning of the term. In the first definition, the contractual and legal character of arbitration. The second definition ignores compulsory arbitration and does not mention its binding character. In the same way, other definitions have some flaws (Ojaghloo, 2008: 17). With these lines, a complete definition of arbitration can be offered as, a method in which two or more beneficiary parties appoint one or more persons (arbitrator or arbitrators) to solve a disputed case according to letter of the law, the general principles of law and rules of equity; the issued sentence is obligatory.

Arbitration is a private procedure approved by law whereby one or more independent person hear the case and decide on the case of dispute. Therefore, arbitration is resolution of dispute between the parties out of court by the person, persons, or third parties they have chosen (Shiravi, 2007: 164). In UNCITRAL Law, arbitration refers to any type of arbitration including by an institution administrated permanently or not (paragraph A of Article 2 of the UNCITRAL Law).

In terms of arbitration characteristics, different views have been expressed:

A) Arbitration is a judgement and belongs to courts. It is an approach to solve disputes where decision of the referee has sealing character and cannot be investigated by judicial or arbitration authority again. The issued sentence is binding for both parties. Of course, it does not mean that the sentence in unchangeable. Nevertheless, the change is limited to (1) interpretation of the sentence by the arbitration judgment references and (2) revision of sentence if it has been predicted in the arbitration contract.

B) Arbitration has a contractual characteristic. Here, referee's authority is resulting from the will of the parties who agreed about the subject of dispute. Any type of sentence imposed on the parties is not the subject of dispute. Therefore, the sentence issued by private referee differs from the sentence issued by governmental sentences because judges has core and essential competencies in legal systems and judgement is a pat of governance. It argues that arbitration is exclusion and parties should agree on it by frreedom of will.

\section{Subject of Arbitration}

Disputes and cases arising from a contract are numerous and different. The fact that all disputes and cases, or a part of them, are subject of arbitrations depends on terms and expressions used in the contract of arbitration. Arbitration agreement may cover all disputes and claims arising from the contract, or it may cover some special cases.

According to Paragraph 6 of Article 33 of the Law on International Commercial Arbitration, if arbitrators issue a sentence outside the jurisdiction inclusions or outside the subject of arbitration, verdict has to be considered a cancellation. Therefore, accurate determination of mandate of arbitrators and the arbitration subject is a crucial point in the contract arbitration. For instance, if parties do agree to refer any sort of dispute arising from the contract to arbitration, due to narrow interpretation of an arbitration clause, Iranian court may do not regard the dispute in the creation or validity of the contract as a term in the contract; hence, it regards the sentence of arbitrators outside the arbitration subject. Meanwhile, if they agree that all cases related to the contract should be referred to arbitration, the interpretation is very vast. To fix the problem, international arbitration organizations such as UNCITRAL and International Chamber of Commerce have regulated some standard terms and they suggest for people to include the terms in their contracts.

In this respect, the following points should be taken into account in setting an arbitration agreement:

1. Words and phrases that are used must fully reflect the intention of the parties to refer all disputes to arbitration or some of them. Parties should assume that an arbitration clause might be interpreted narrowly; thus, the explanations that loosely cover all proceedings may be taken into account by the Court carefully in limited implications. If a dispute occurs and the parties wish the matter to arbitration, they can refer the dispute to arbitration by inclusion of one or more legal aspect. If they agree to refer only some parts of the contract to arbitration, parties should be aware not to set the agreement so that the nature of intended part should not be in effective relation to other parts. Failure to do so will limit the arbitrators to consider the subject of dispute fully and comprehensively because their consideration may transgress the extremes of arbitration agreement and nullify the arbitration sentence (Judicial and Legal Journal, 1978: 26).

2. If the disputes and claims have not occurred yet, and parties have not decided about possible future disputes, it is better to subject all disputed resulted from the contract, instead of some of them, to decisions on other 
parts of the contract, which arbitrators have not the jurisdiction in other parts. For instance, if a sale contract sets that only disputes resulting from 'product compliance with the terms of the contract, or its defects' should be referred to arbitration, arbitrators may confront with the defense that the reason for product' defect has been buyer's delays in customs clearance or payment. Here, since the arbitrators' sentence about delay and so on is out of the arbitration agreement, arbitrators' sentence can be invalidated.

\section{Law in International Commercial Arbitration}

In general, international commercial arbitration is an instrument resolution of complex disputes in international business activities in transboundary field (Born, 2009: 68). For the detection of international and domestic arbitration, it should be said that international arbitration for the Iranians is relevant when one party is not a citizen of Iran at the time of conclusion of the arbitration agreement (Paragraph II of Article 1 of Iran Arbitration Law). UNCITRAL Model Law on International Commercial Arbitration of 1985 (amended in 2006) has discussed the instances of international in details. According to Article 1 of the law, arbitration is international if:

1. Business center for the parties of arbitration agreement should belocated in different countries at the time of conclusion of the contract.

2. One of the following places should be outside the country determined as the business center of the parties"

A) Arbitration location; if arbitration agreement is determined according to it.

B) Every place that the obligations arising from the business relationship should be implemented in the area or a place where the main subject is in the most relationship with it. For instance, the place of production of goods or its delivery can be regarded as a place near to the place of implementation.

3. Parties expressly agreed that the subject of arbitration relates to more than one country (Joneidi, 2001: 130).

\section{Case Arbitration and Institutional Arbitration}

Iranian arbitration procedure is a case arbitration because not only it is silent about the possibility of arbitration by legal persons but also it stipulates that all persons are able to refer their dispute to arbitration of one or more persons. According to many lawyers and experts, institutional arbitration is not considered. Therefore, Iranian law had no regulation that involves the formation of an institution for arbitration ant it was an unfamiliar concept in the vocabulary of Iranian law before adaptation of Iranian Law on International Commercial Arbitration, which was adopted from UNCITRAL Rules; the changes in its content approved by parliament in 1997 (Zarrabi, 1391: 147).

Statute of Arbitration Centre of the Chamber of Commerce, Industries and Mines of Iran was adopted in the implementation of third paragraph of Article 2 of Law on Amendment of the Law on Chamber of Commerce in 2000 and the Center was regarded as a private institution. It is one of the most important and prestigious judging organization in Iran by utilization of expert judges consisting of prominent and highly qualified lawyers and experts in the field of arbitration aw sell as traders that their list is available on the website of the Chamber of Commerce. It is noteworthy that Arbitration Association of America had more than 19 thousand arbitrators in 1991; since the Iranian organization id newborn, the number of arbitrators is not comparable to the number of arbitration cases (ibid: 149). The Iranian arbitration act noted two types of arbitration: (1) Case Arbitration and (2) Institutional Arbitration. The Law has not presented any definition of case arbitration and institutional arbitration. It can be argued that in case arbitration, parties must predict many details of the arbitration and proceedings practices or they may use some predetermined provisions by UNCITRAL arbitration regulations. In institutional arbitration, the details of the arbitration and proceedings practices are mentioned in the regulations of the referred institution like the rules of arbitration of International Chamber of Commerce" (Shiravi, 2007: 507).

Institutional arbitration is usually preferable to case arbitration. Institutional arbitration has characteristics that distinguish it from case arbitration. Technical, professional and expert advice and to carry out all stages of arbitration to the end of the proceedings are important characteristics of institutional arbitration. Saving time and money to achieve the desired result in disputes in arbitration organizations is another of characteristic of this arbitration. Since arbitration has essentially a contractual nature and the arbitration services are provided pursuant to mutual agreement, the relationship between arbitration organization and the parties will have a contractual nature. Arbitration organization is a facilitator in referring the case to arbitrator. It heads administrative, regulatory and expertise roles to the issuance of the sentence. It manages unforeseen matters that may emerge in the conflict resolution process. The last item makes the advantage of institutional arbitration to case arbitration more explicit (Karvari Nasab, 2011).

Admittedly, institutional arbitration takes place in accordance with the arbitration rules of the concerned 
organization and the dispute parties are committed to its proceedings by submission of the dispute to arbitration organization. In addition to giving priority to the agreement of the parties, institutional arbitration procedures provides solutions to issues not foreseen in the arbitration agreement and compensates the gaps in arbitration agreement in this regard (ibid: 2011).

With regard to the necessity of institutional arbitration and technical management of arbitration as well as Referring to paragraph 8 of Article 6 of the Law on International Commercial Arbitration, Iran the possibility of institutional arbitration and practicing some relevant judgments to court have been recognized in Iran. In addition, Article 5 of the Statute of the Arbitration Center of the Iran Chamber has predicted the establishment of Arbitration Center of the Iran Chamber in order to resolve issues of domestic and foreign trade.

Commercial Arbitration Act of Iran has empowered the parties to determine the arbitration type and make decision about law governing the arbitration procedure, the number of arbitrators, the place of arbitration, lawsuit settlement based on justice and equity, etc. The only difference between case arbitration and institutional arbitration relates to the details of proceedings. It is pre-determined in institutional arbitration; but it should be determined and agreed by parties in case arbitration. Despite the powers given to the parties in the law of international commercial arbitration about determination of jury and proceedings practices, it has established limitations in some cases that is necessary to follow them anyway. (Safaei, 1996: 45).

For the arbitration agreement, whether case or organization, to enjoy from the advantages of international commercial arbitration law, the followings should be observed in setting the arbitration agreement:

1. If an Iranian is a party to the agreement and parties want to refer the case to arbitration in the future, Iranian side has no right to select arbitrator or arbitrators who have the citizenship of other party's country.

2. If the parties are determined to appoint certain individuals as arbitrator in their contract, they should be aware that the arbitrators may doe not prefer to be involved in arbitration. According to Article 5 of the Commercial Arbitration of Iran, if the parties select certain persons for arbitration and the arbitrators will not compromise as the new arbitrator or arbitrators, arbitration agreement can be set without specifying arbitrators. To avoid this unpleasant outcome, a mechanism must be established to determine new arbitrators.

3. Arbitration agreement is valid even if the parties have not agreed on the composition of the jury, the ways to choose and the procedures. In this case, the arbitration process shall be conducted in accordance with the provisions of the Law on International Commercial Arbitration. Failure to comply with these regulations will allow a party to regard the issues sentence revocable. Article 19 of the Law on International Commercial Arbitration stipulates:

A) The parties may agree on the procedure subject to the mandatory provisions of the law.

B) In the absence of such an agreement, the arbitrator can manage arbitration in an appropriate way in compliance with regulations of this Act. Recognition of the relationship, relevance and value of any reason is carried out by the arbitrator (Joneidi, 1997: 23).

\section{International Trade Arbitration Agreements}

Contract literally means the parties' agreement to create a legal effect. The result of contract may be the creation, change, or abrogation of obligations or it may be creation, change, or abrogation of a real right (Imami, 2008: 135). With respect to the subject of this article, contracts are classified in two general groups: civil contracts and commercial contracts.

In general, a contract is commercial when the subject of its obligation is its. Commercial obligation results from commercial activities (Safaei, 2005: 17). The distinguishing criteria between civil and commercial contracts are the court's rules and decisions. Therefore, commercial contract refers to an agreement that commitments or obligations agreed by parties (at least for one of them) relates to commercial transactions. In other words, when commercial activities or transactions are in form of contractual rights, they are called commercial contracts. Principally, the first aim of parties at the time of agreement is execution of the contract in good faith and all honesty; however, one or both parties may refuse running it at its specific time (Eshraghi Naraghi, 2013: 60).

Arbitration and dispute settlement agreed by contract complying with the comments and ideas of a third party has deep roots in history. For instance, Phoenician and ancient Roman merchants used this type of judgement. Arbitration agreement is a contract whereby parties agree to appoint one or more specific persons to solve their current dispute, either proposed to a court or not, or their probable dispute in the future (Shams, 2007: 164). Arbitration agreement may be determined as an arbitration clause in the contract or a separate contract (Paragraph (c) of Article 1 of the Arbitration Act of Iran). Arbitration agreements on the core issues related to arbitration (Shiravi, 1999: 65). According to the 
arbitration agreement, an arbitrator will be allowed to handle disputes and issue sentence. The agreement specifies the scope of authority of arbitrator (Siravi, 2007: 501). Arbitration agreement may be in form of an arbitration contract or an arbitration clause in the contract (ibid: 105).

About the validity or invalidity of an arbitration clause in the case of invalidity of the original contract, some believe that the relationship between the main contract and arbitration clause is in principle like the relationship between original contract and other provisions; therefore, this arbitration clause depends on the main conclusion. Hence, none of the parties can terminate the arbitration clause before termination of the main contract. In the event of termination or annulment of the main contract, commitment of the arbitration clause will be void. However, Paragraph 1 of Article 11 is the opposite of this theory. It states that an arbitration clause that is mentioned as a part of a contract is regarded as an independent agreement in terms of law execution. The decision of the arbitrator about invalidity and acting cancellation of the contract does not mean the validity of arbitration clause contained in the contract. There is disagreement among experts about nature of arbitration. They are summarized in three theories: $(A)$ contract theory; (B) combined theory; (C) independence theory (Sadeqi, 2003: 28-29).

\subsection{Contract Theory}

Under this theory, arbitration arises from a valid contract between the parties and its conclusion depends on the form and content of the contract as well as the consent and will of the parties. Therefore, arbitration process must follow the will of the parties that is reflected in the contract (Cairton, 1952: 635). This theory provides a clear picture of the relationship between parties and arbitrators; but it does not provide a response to compulsory arbitration and referable issues to arbitration. In addition, immunities, competencies and duties of the judges are not quite clear in this theory (Sadeqi, 2003: 29).

\subsection{Combined Theory}

According to this theory, arbitration is an institution that has two contractual and judicial characteristics. On the one hand, arbitration requires the agreement by both parties about submission of the dispute to a private person. On the other hand, arbitration has the characteristics of a trial that distinguishes it from non-judicial dispute resolution methods such as reconciliation, etc. Judicial and contractual elements are close together in all processes of the arbitration. However, this theory has been criticized in terms of lack of separation between judicial and contractual elements (ibid).

\subsection{Independence Theory}

Contrary to previous theories, it focuses on the goal of arbitration. According to this theory, arbitration parties should have unlimited authority to be able to decide about the method of arbitration. The difference between this theory and contract theory is that he will of parties in limited in contract theory. The theory has been criticized since it is an ideal and unreal contract that lacks a clear framework for arbitration (ibid).

\section{Islamic Law and Law on International Trade Arbitration}

Judgement means two persons determine a third person for solving their dispute. The act of making decision about the persons is called judgement (Muhammadi Gilani: 1983: 26). In Imamia jurisprudence, arbitration has been included under the title of judgment or religious judgment; the referee is called judge or uninstalled judge. However, it can be said that the determined judge in this regard is to some extent equal to arbitrator in international commercial arbitration because accuracy in terms of jurists and regarding its comparison to arbitration institution shows that they are two different institutions with a same goal.

Sahid Thani says that a determined judge in this regard is person who has been specified by parties in the presence of appointed judge by the Imam (AS) (Sahid Thani, 1996: 364).

About the legacy of predetermined judge, one should refer to Quran as the first source of legitimization. Verse 35 of Al-Nisa says, "And if you fear a breach between the two, then appoint judge from his people and a judge from her people; if they both desire agreement, Allah will effect harmony between them, surely Allah is Knowing, Aware." It is a known proof for legitimization of predetermined judge. Some refer to the verse "و من لم يحكم بما انزل" (meaning "And whoever did not judge by what Allah revealed, those are they that are the unbelievers" Al-Maida: 47). This verse argues that whoever refuses to obey God is an unbeliever. Therefore, dispute parties ask the third person to make a decision; if 
one refuses, he will be included in the threat of this verse. In this way, the third party must accept the judgment and his decision is effective; in other words, his sentence is obligatory and disobeying it is unlawful (Muhammadi Gilani, 1983: 36).

It is said that one can refer to verses about enjoining good to prove the legitimization of predetermined judge, as elimination of a dispute is a good behavior. As Sahib Jawahir does not accept predetermined judgement in the age of Imam's absence, he refuses to refer to verses about enjoining good; he argues that these verses does related to making decision about people. He also rejects the reference to the verse in Al-Maida. He states that this verse has been limited by veree 56 of Al-Nisa "فلا و ربك لا يومنون حتى يحكموك فيما شجر بينهم" (meaning "But no! by your Lord! they do not believe [in reality] until they make you a judge of that which has become a matter of disagreement among them, and then do not find any straitness in their hearts as to what you have decided and submit with entire submission") (ibid: 26).

There are also some hadiths or narratives about the legitimization of predetermined judge. In Abi Khadija hadith, in

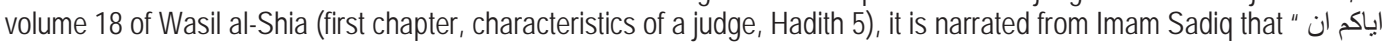

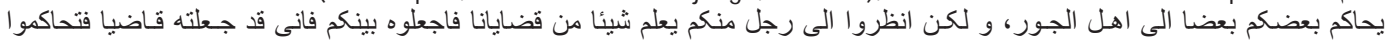
"اليه. It means, "Our Shiites should not bring their case to the oppressors; but they should select one who is knowledgable among themselves as judge; he should be confirmed by Imam as judge. The context of this hadith is in line with selection of a predetermined judge because their installment was nonsense on the opposite cases. In Omar ibn Hanzaleh narration about the characteristics of a judge, Imam Sadiq argues, "نظر فى حلالناو حرامناو عرف احكامنا فليرضوا به حكما فانى قد "جعلته عليكم حاكما.". There are other hadiths about the validity of a predetermined judge (Qomashi, 1993: 215).

The sentence of a predetermined judge is compulsory for both parties. After the sentence issuance, parties' consent has no influence on its implementation (Muhqiq Helli, 1409: 168). There are two ideas in this regard. One may say that it is necessary for the contract parties to obey the sentence after its issuance; another person may argue that in the case of intransigence, the sentence is not effective. Shahid Thani accepts the first idea because one should act as what has been mentioned in hadiths.

Specifying the characteristics of a predetermined judge is an important issue. Most jurists believe that a predetermined judge should have all qualifications of ordinary judge except installment by an Infallible Imam. Mohaqiq Helli's Sharaye, Shahid Thani in Dorus and many other jurists agree this idea. The necessary conditions for a judge according to jurists are maturity, perfection of wisdom, purity of birth, manhood, ijtihad, faith, justice and installation. Some of these qualifications seem rationally necessary for predetermined judge including wisdom, justice and to some extent maturity. Therefore, they are valid for commercial arbitrator. The need for some of these requirements in commercial arbitration can be questioned seriously; such as purity of birth, manhood, ijthad. They have not mentioned neither in the new Civil Procedure Code (2000) nor in Law on International Commercial Arbitration (1997). Guardian Council as the reference to detect mismatch with legal regulations has also approved this law. As noted earlier, predetermined judge and arbitration in commercial disputes are common in literal points. However, it is not possible to put their similarities away and regard them as two different institutions (Darabi, 2006: 340).

Another controversial issue for predetermined judgement is the validity of predetermined judge in the presence of Infallible Imam; Shahid Thani and Sahib Jawahir agree this idea. In this regard, predetermined judgement is rejected at the age of absence according to this belief. Shahid Thani states that if the judge is Moujtahid, his rule is effective and there is no need for predetermined judgement. If he is not Mujtahid, jurists agree that his rule id not effective. Accordingly, predetermined judgement is allowed only by observing all conditions at the time of Imam's presence and non-installment of a judge by Imam (ie. Parties' agreement) (Law Journal, 1991).

\section{Referring to International Commercial Arbitration}

Referring to arbitration is carried out by the parties' consent and arbitration is contractual. This agreement is valid when it has the basic conditions of contracts accuracy, subject of Article 190, including intention of the parties and their consent, capability of the parties, consistency with the rules of public order and ... . Law on International Commercial Arbitration stipulates that arbitration agreement is an agreement between the parties whereby all or a part of a dispute about one or more certain legal relationship including both contractual and non-contractual matters that have been arised or may be arised are referred to arbitration. Arbitration agreement may be as an arbitration contract in the contract or an independent contract (Alizadeh, 2001: 30).

\subsection{Arbitration Clause and Issues Capable to be referred to Arbitration:}

Referring a dispute to arbitration may be included in an international convention so as to be called arbitration clause. The 
difference between arbitration clause and arbitration contract can be described as follows: when parties conclude a contract on a subject and predetermine judgement on the future disputes in a clause of the original contract they have established an arbitration contract. Nevertheless, when parties disagree about commitments that they have for each other in the original contract and there is no reference to arbitration in the main contract, they will establish a new agreement to solve the problems in an independent agreement; the new agreement is called arbitration contract. Contrary to arbitration contract, arbitration clause does not consider the arised disputes and claims, but it covers contingent claims and disputes among the committed countries (Judicial and Legal Journal, 1978: 51).

Arbitration clause may be general or specific. The general clause is when all disputes are agreed to be referred to an arbitrator provided that its nature should be referable to arbitration.

Special clause is regarded for implementation and interpretation of a treaty in which reference of some specific points are included in the contract such as treaties of peace and commerce and so on. Almost all people can be invited to court and arbitration by referable issues to arbitration. However, it is not possible to force a person to accept arbitration contrary to his will. Iranian legislators have excluded claims about bankruptcy, marriage, and divorce from subjects of arbitration. Due to their specialized nature, these claims cannot be investigated by every person except jurists. Therefore, these claims are not in the competency of arbitrators. As bankruptcy has a public aspect, it is entry into force for private persons (Shahla, 2004: 45).

\title{
8.2 Necessary Conditions before Arbitration Contract
}

In Iran, parties must be qualified to refer the case and an arbitration contract to be regarded valid. Article 3 of the Arbitration Rules of the Arbitration Center of Iran Chamber states that all persons, natural or legal, that have a capacity to institute a suit may by mutual consent, refer their disputes to the Arbitration Centre, whether the dispute has been filed with the judicial authority or not. The said consent includes the consent arising out from Arbitration Agreement and from submission by one party to the Centre with an offer of arbitration and acceptance of it by the other party (ibid: 46).

Identifying the qualifications of natural persons is not difficult; for legal persons, more attention is required to identify whether the contract signer has a legal qualifications for signing or arbitration on the current or future disputes. This knowledge is obtained by information about legal person statutes and other documents on behalf of delegation. The difficulties relate to the governments, companies and public organizations, which has limitations in referring their disputes to arbitration. For instance, Article 139 of the Constitution of Islamic Republic of Iran determines some limitations as following:

\begin{abstract}
"The settlement of claims pertaining to public and State property, or the referral thereof for arbitration, shall depend in all cases on the approval of the Cabinet, and brought to the notice of the Parliament. In cases where one party to the dispute is a foreigner, or when it is an important domestic case, the approval of the Parliament must also be obtained. The important cases will be specified by law" (Eskini, 1990: 18).
\end{abstract}

Despite the second paragraph of Article 2 of the Law on International Commercial Arbitration of Iran that all persons can institute a suit, if the subject of suit is public or state properties, it should be approved by Iranian Parliament. Therefore, arbitration contract should be approved by Iranian Parliament in addition to registration of person's representation. It should be noted that it does not belong to only Iran and all countries influenced by Napoleonic Code have stipulated some limitations for public organizations and state-owned companies to refer their disputes to international arbitration. For example, based on Articles 83 and 1004 French Code of Civil Procedure, the French government and state-owned companies have not the capacity to institute a suit in an international arbitration.

According to Article 2 of the Arbitration Rules of the Arbitration Center of Iran Chamber and Article 5 of the 1958 Convention, identifying and enforcement of foreign arbitration and non-capacity of one party will invalidate the sentence, or cancel its enforcement. Therefore, the capacity of the party should be investigated before conclusion of a contract.

\subsection{The Capacity to refer a dispute to Arbitration}

Another important point, which should be regarded before setting an arbitration contract, is the subjects that are capable to be referred to arbitration. Paragraph 1 of Article 34 of the Arbitration Rules of the Arbitration Center of Iran Chamber, the arbitrator's sentence is invalid in the following cases:

1. If the subject of dispute is not solvable by referring to arbitration according to Iranian codes. For example, according to Article 496 of Code of Civil Procedure, claims about bankruptcy, marriage, and divorce are not 
referable to arbitration. In some countries, claims about assurance of free trade competition as well as industrial ownerships are not referable to arbitration (ibid: 23).

As an instance, paragraph 1 of Article 32 of International arbitration bill about "Termination of proceedings" says:

1. The arbitration proceedings conclude or terminate by an award or a decision of the Arbitrator in the following cases:

A. One of the parties had not the capacity.

B. Arbitration contract is invalid according to the rule on which they conclude their contract. In the silence of the contract, Article 31 and 32 of

Article 31- In international arbitrations each of the parties may within 30 days after the service of the award request for correction of any clerical, typographical, computation errors in the Award or request for an interpretation and clarification of the award, or issuance of a supplementary award with respect to a matter which are submitted but remains undecided (Jafarian, 195: 184).

Article 33- (1) at the request of either of the parties, any dispute between them about the meaning and scope, the sentence will be referred to the reference of judgment within three months from the date of judgment.

(2) At the request of either party, the dispute will be referred to the International Court of Justice if it were impossible to refer the dispute to the reference of judgment and the parties could not reach a conclusion according to paragraph one of this Article.

(3) The Arbitrator shall decide on request for correction or interpretation of the award within 30 days after the receipt of the request, and on a request for supplementary award within 60 days extendable if necessary, after receipt of such request, if he considers such request justified.

(4) The regulations of this law have been disregarded about notification notices of appointment of arbitrator or arbitration request.

(5) Applicant of the annulment, for reasons beyond his control, has not been able to present his evidence.

(6) The arbitrator has issued a sentence outside the scope of his authority. If the issues referred to arbitration are separable, only the part of the sentence that has been outside the scope of his authority is invalid.

(7) The settlement of jury or procedure is not in accordance to the arbitration agreement; or in case of silence or absence of agreement, arbitration is contrary to provisions of this law.

(8) The arbitration conclusion complies with the arbitrator's positive and effective idea whose crime has been proved according to Article six of this law.

(9) Arbitration award was based on a document that its falsehood has been proved according to thefinal sentence.

(10) After issuance of arbitration award, new proofs indicate the legitimacy of the revocation request and it is proved that the documents have been covered by another party (ibid: 185).

\section{The Effect of Breach of Contract in International Sales}

The doctrines for foreseeable breach of contract are predicted in Article 72. This article stipulates:

(1) "If prior to the date for performance of the contract it is clear that one of the parties will commit a fundamental breach of contract, the other party may declare the contract avoided.

(2) If time allows, the party intending to declare the contract avoided must give reasonable notice to the other party in order to permit him to provide adequate assurance of his performance.

(3) The requirements of the preceding paragraph do not apply if the other party has declared that he will not perform his obligations." (Nategh Noori, 2009: 120).

For the dissolution of the foreseeable result of a breach of contract in Convention on the International Sale of Goods, it should be said that the promisee's right for dissolution of the contract before the expiry of the deadline occurs in the case of lack of performance by other party; it is expressly described in Article 27 of identification Convention to implement its conditions. Before focusing on the conditions for invoking this right, it is necessary to understand sources and bases that are helpful to justify this particular form of the right to dissolve. As it is known, the right to dissolve a contract has several instances with very different legal effects; thus, one should be fully aware of the guarantees predicted by the Convention for foreseeable contract violations. In this way, the acceptable instances of the right for dissolution of contract would be uncovered (Ghafari Farsiani, 2009: 235).

One of the most important legal grounds used to justify foreseeable breach of contract and its executive guarantees is the early breach of contract by the promised, breach of an actual obligation (or the breach of an implied term) (Corbin, 1952: 179). There is an implied term in the contract stating that the parties should not commit an action to prevent the implementation of the contract. This duty is imposed according to the principle of good faith; it requires the 
rational behavior of the parties in the execution of their obligations (Winthrop, 1924: 333).

When the promised notifies, or it is proved in any way, that he is not committed to his obligation and he refuses his obligations in the maturity, it is the time of contract breach and waiting for the due performance of the obligation is no longer relevant. According to this view, there is an implied term in every contract stating that parties have pledged to respect the so-called contract between them and adhere to it. The implied term is implicit signified of contract terms that are essential terms of the agreement or the nature of the contract according to reason, law or custom; since it is proved through secondary references, attention to it is not necessary. As the parties do not show any objection, they are adhering to the signified aspect of their words (Katouzian, 2008, vo. III: 119).

One may object that breach of an implied term is indeed actual breach of contract not its possible breach. In response to this objection, it can be said that although applying the theory is based on a real violation in this case, the base of actual breach is accepting a possible breach of contract in the future and a way to accept effects of a possible violation. It's not only okay but also facilitate the admission of theory.

\section{Conclusion}

Apart from the problems related to claims about international trade in the national courts, ensuring the implementation of verdicts in other countries is a very important issue. Enforcement of rules of one country is not easy not easy in another country and it may be fulfilled in specific and difficult ways. With the expansion of international commercial arbitration to resolve disputes among different nations, it was replaced to court and judicial proceedings. This need to find new ways to ensure the implementation of the sentences issued in one country in another country; the new ways should prevent the votes to be stopped by the implementation of the courts. Some countries, either individually or in groups, began to response this important need. After the legislation of international trade arbitration in 1997, Iran has determined the ways to hold international arbitration in Iran; hence, the possibility of holding the international commercial arbitration was realized. It should be clarified in international commercial interactions that how the sentences issued outside Iran would be identified and enforced in Iran or vice versa. An important step was taken in connection with the spread of international commercial arbitration in Iran with the approval of international commercial arbitration act. Another step was necessary to set Iran as an appropriate place for holding international arbitrations; it would recognize Iran as a secure and adherent country of international arbitrations. The need was establishment of rules for the recognition and enforcement of arbitral awards issued abroad. Accession to the 1958 New York Convention about recognition and enforcement of foreign arbitral awards was the best solution used by Iran in 2001. Whereby, not only arbitral awards issued abroad has been capacity to be identified and enforced but also arbitral awards issued in Iran can be enforced outside Iran.

According to Article 9 of the Civil Code, the convention is known as a domestic law. In this regard, arbitral awards issued outside Iran can be enforced in Iran.

Legal systems are moving toward foundation of a developed complex legal structure in terms of international commercial arbitration process. Arbitration procedure has been established as an alternative to court proceedings and it has reached its final destination while it has been approved by courts, domestic law and international treaties. The establishment and effectiveness of international arbitration in the first place is postponed to identification and authentication of parties' agreement to refer commercial disputes to arbitration and in the second place to enforcement of foreign arbitration. In comparison to foreign court judgments, arbitration, as a method of resolving commercial disputes, is easier and applicable. Law enforcement of foreign courts is less under the judicial control of the issuance place; either appeal or other forms of revision on rulings.

The most important issue facing the process of arbitration in international trade is expectations and fulfilling mission that has taken; in other words, establishing effective uniform substantive law and procedural law of international arbitration. Nowadays, arbitration is in a range that judicial process by the courts is located on the one side and compromise or mediation is placed on the other hand. In this regard, United Nations Commission on International Trade Law, known as UNCITRAL that had developed arbitration rules for international applications (1961) has adjusted some new suggestions for those wishing to resolve their differences amicably. Another good measure by UNCITRAL is the preparation of Model Law on International Commercial Arbitration (1985), which is in fact the completion of the necessary elements for the establishment of the institution of arbitration and its strong effect.

\section{References}

A. Amrtin, Elizabeth (2005). Oxford Dictionary of Law. Tehran: Didar Publication.

Alizadeh, Abdolreza (2001). "Comparison of International Commercial Arbitration Act and some other laws." Strategic Management Journal, spring 2001, No. 23 and 24, pp. 46- 7. 
Alsan, Mustafa (2013). "Legislative strategy and referral to the appropriate law on international commercial arbitration: IRI case of Ministry of Defence of Iran against Cubic." Journal of Strategy, summer 2013, Issue 67, pp. 32-7.

Aria Kia, Reza (2009). "The arbitration provisions in course of the international oil and gas contract law." Journal of International Law, fall and winter 2009, No. 41, pp. 217-98.

Bordbar, Muhammad Hossein (2005). Competency in international arbitration tribunals. Tehran: Phoenix.

Born, Gary B., International Commercial Arbitration, Netherlands, First Edition, Kluwer International Law, 2009, P.68

Cairton, Kenneth S. (1952). Theory of The Arbitration Process , Law And Contemporary Problems, Number 4, Volume 17 , Autumn 1952 ,P. 635

Corbin. Arthur Linton , 1952, Corbin on contract, west publishing company, one volume edition, United States..

Darabi, Muhammad Hadi (2006). "Introduction to national and international commercial arbitration." Strategy Journal, fall 2006, No. 41, pp. 317-350.

Dehkhoda, Ali Akbar (1993). Dehkhoda dictionary, Tehran, Tehran University Publication.

Eshraghi Naraghi, Mojtaba (2013). Legal-economic analysis of forecast for breach of contract. Journal of Business Research, winter 2013, 60-82.

Eskini, Rabia (1990). "Government and public organizations in referring to international commercial arbitration." Journal of Law and Political Science, Tehran University, January 1990, No. 25.

Eskini, Rabia (2006). Training leaflet of international arbitration. Qom: Mufid University.

Ghafari Farsani, Behnam (2009). Foreseeable effect of a breach of contractual relationships. Quarterly of Law, Faculty of Law and Political Science at Tehran University, issue 39, No. 2, winter, 2009, pp. 233-256.

Ilkhanizadeh, Negar (2007). "Regulating arbitration agreement according to Iranian law international commercial arbitration." Journal: Bar Association, winter 2007, №. 198 \& 199, pp 39-67.

Imam, Seyed Hasan (2008). Civil Rights. Volume 1, twenty-eighth edition, Tehran: Islamia.

Jafarian, Mansour (1994). "Two legal research: Reflections on international commercial arbitration Act." Parliament and Strategy Journal, January and February 1994, No. 13, pp. 109-142.

Jafarian, Mansour (1995). "Legal Research: Reflections on international commercial arbitration Act." Parliament and Strategy Journal, June and July 1995, No. 16, pp. 175-208.

Jonedi, Laya (1997). Law Governing International Commercial Arbitration. Tehran: Publication of Justice.

Jonedi, Laya (2001). "Law on International Commercial Arbitration from the valve of Islamic law." Matin Journal, spring 2001, No. 10, pp. 138-127.

Judicial and Legal Journal (1978). Office of International Legal Services of the Islamic Republic of Iran, No. 14-15.

Karvari Nasab, Mahshid (2011). (An arbitrator in Arbitration Centre at Iranian Chamber of Commerce). Institutional arbitration and international commercial disputes. Retr.from < http://www.edalateno.com>

Katouzian, Naser (2008). General rules of contract. Fifth edition, vol 3, Tehran: Enteshar Corporation.

Muhammadi Gilani, Muhammad (1983). Justice and Judgment in Islam. Tehran: Al-Mahdi Publication, Fourth Edition.

Muhaqiq Helli (1402). The laws of Islam in the Halal and Haram issues. vol. 4, Tehran: Esteghlal, Second Edition.

Nikbajht, Hamidreza (2000). Workshop on International Commercial Arbitration. Journal of Legal Research, spring \& summer of 2000, No. 29 and 30, pp. 239-252.

Ojaghloo, Rasoul (2008). "The substantive law prevailing in international commercial arbitration." Journal of Business Review, September-October 2008, No. 31, pp. 16-26.

Qomashi, Muhammad Said (1993). "Consolidation judge or the policy of judgment privatization." Journal of Ahlul Bayt Jurisprudence, No. 10.

Reif, Linda C., Conciliation as a Mechanism for the Resolution of International Economic and Business Disputes, Fordham International Law Journal, Volume 14, Issue 3, 1990, p. 580.

Sadeqi, Mohsen (2003). "Court intervention in international commercial arbitration." Journal of the University of Mufid, spring and summer 2003, Issue 1.

Safaei, Seyed Hossein (2005). General rules of contracts. Fifth edition, Tehran: Mizan Publication.

Safaei, Seyyed Hossein (1996). International law and international arbitration, Tehran: Mizan Publication.

Shahid Thani (1996). Al-Rawdạh al-bahīyah fĩ sharh al-Lum ’ah al-Dimashqīyah. Vol. 1, Qom Institute of Ismaili, Third Edition.

Shahla, Mahdi (2001). Booklet of international arbitration. Islamic Azad University: School of Law.

Shams, Abdollah (2007). Code of Civil Procedure (basic course), Tehran: Derak, Volume II.

Shiravi, Abdol Hossein (1999). "Regulating international commercial arbitration contract according to the law." Journal of Higher Education Complex, fall 1999, Issue 3, Pages 65-84.

Shiravi, Abdol Hossein (2007). International Trade Law. Tehran: SAMT, Sixth Edition.

Strong, S. I., Beyond International Commercial Arbitration? The Promise of International Commercial Mediation, Washington University Journal of Law \& Policy, Volume 45, 2014, p. 12

Tawasoli Naini, Manouchehr \& Sima Badrizadeh (2011). "Identification and enforcement of arbitral decisions issued by international business in cyberspace." Mufid Journal, winter 2011, No. 88, pp. 123-146.

Winthrop Ballantine, Henry, Feb 1924, Anticipatory breach and the enforcement of contractual duties, Michigan law review, vol.22.

Zarrabi, Mitra (2012). "Similarities between the UK Arbitration Act 1996 and international commercial arbitration law of Iran." Mufid Journal. Summer 2012, Issue 91, pp. 141-160. 